\title{
Energy rating for green buildings in Europe
}

\author{
M. Carpio ${ }^{1}$, A. García-Maraver ${ }^{2}$, D. P. Ruiz ${ }^{3}$, A. Martínez ${ }^{4}$ \\ \& M. Zamorano ${ }^{2}$ \\ ${ }^{1}$ Department of Building Construction, University of Granada, Spain \\ ${ }^{2}$ Department of Civil Engineering, University of Granada, Spain \\ ${ }^{3}$ Department of Applied Physics, University of Granada, Spain \\ ${ }^{4}$ Instituto Tecnológico de Certificación Energética (ITCEA), \\ Granada, Spain
}

\begin{abstract}
The building sector is one of the main bodies responsible for primary energy consumption in Europe. Consequently, energy certification of buildings is being promoted under the policy to monitor and reduce energy consumption. By means of the European Directive 2002/91/EC on the Energy Performance of Buildings (EPBD), and the recast in the Directive 2010/31/EU, the legislative framework for all members of the European Union has been created and certification has become compulsory in all Member States. The primary aim of this energy framework is saving final energy and in consequence any related parameter such as primary energy, $\mathrm{CO}_{2}$ emissions or energy costs, without compromising comfort or productivity.

Green building rating systems are developed to provide independent assessment standards that evaluate in a few categories about the performance and sustainability of buildings. However, and despite being based on the same legislative framework, the energy performance of buildings is calculated in different basis of methodology depending on the European country or region, and thus the same category might weigh differently in each of the rating systems.

Therefore, this paper aims to compile and compare the existing energy rating systems in European countries in order to better ascertain the uniformity of energy performance evaluation.

Keywords: energy rating, buildings, European framework, $\mathrm{CO}_{2}$ emissions.
\end{abstract}




\section{Introduction}

The attenuation of climate change is a global priority due to the fact that $\mathrm{CO}_{2}$ emissions are one of the greatest precursors of it [1]. With this purpose, the European Union created a legislative framework for all its member countries based on the Kyoto Protocol [2] by carrying out the corresponding transposition according to the necessities of each country. This framework is composed of the Directives 2002/91/EC [3] and 2010/31/EU [4] on Energy Performance of Buildings (EPBD).

Buildings dedicated to living quarters are responsible for $40 \%$ of the energy consumed and $36 \%$ of the $\mathrm{CO}_{2}$ emissions to the atmosphere in Europe [3, 4]. Therefore these normative regulations were necessary to reduce this environmental impact generated by the building sector.

The regulation in terms of energy efficiency in buildings is critical for the assignment of the Qualified Experts (QEs) that will be involved in the process, as well as for their authorization and official tools to issue Energy Performance Certificates (EPCs) [5-7].

Throughout these regulations, the European objective is to achieve a Nearly Zero-Energy Building (NZEB) and thus make a comfortable building with minimum energy consumption by insulating the building envelope or encouraging the use of renewable energy in air conditioning systems, heating systems and domestic hot water (DHW), amongst other improvements for the accomplishment of savings in energy demand, $\mathrm{CO}_{2}$ emissions and economical factors.

Taking the situation previously described into account, the objective of this review is to make a comparative analysis of the different transpositions of the EPBD within the European appointed countries (EU-28 and Norway).

\section{Energy framework}

The current challenge for the global energy sector is double: (i) increase dramatically the access to affordable and modern energetic services in countries that lack them and (ii) find the combination of energy sources, technologies, policies and behavioural changes that will reduce adverse environmental impacts [8]. A considerably large number of measurements have tried to be implemented as a response to the necessary fight against climate change; some of them are analysed in the section below.

\subsection{Kyoto Protocol}

The Kyoto Protocol [2] sets binding targets for 37 industrialized countries and the European community for reducing GHG emissions to an average of $5 \%$ against 1990 levels over the five-year period 2008-2012, varying among the different developed countries. By the end of the first commitment period of the Kyoto Protocol in 2012, a new extension for the period 2013-2020 was negotiated and ratified in order to deliver the stringent emission reductions the 
Intergovernmental Panel on Climate Change (IPCC) had clearly indicated were needed.

Buildings are responsible for more than one third of total energy use and associated greenhouse gas emissions in society, both in developed and developing countries [9]. Therefore, the building sector is a large source of GHG emissions and has significant potential as a source of cost-effective emissions reductions [10]. With proven and commercially available technologies, the energy consumption in both new and old buildings can be cut by an estimated $30-50 \%$ without significantly increasing investment costs [10].

\subsection{Directives 2002/91/EC and 2010/31/EU on the energy performance of buildings}

To play a leading role in the reduction of greenhouse gases emissions, the European Union wanted to develop as quickly as possible a common position in the fight against climate change, and thus implemented its own measures to deal with climate change. In this regard, and due to the fact that more than $40 \%$ of EU energy consumption depends on buildings [11, 12], the Energy Performance Building Directive (EPBD 2002/91/EC) introduced the compulsory energy certification of buildings in the EU from 2006 and it has played a key role in the common policy to monitor and reduce energy consumption [12]. The recast of the EPBD in $2010(2010 / 31 / \mathrm{EU})$ seeks to clarify certain aspects of the 2002 Directive, extend its scope, strengthen certain provisions, and give the public sector a leading role in promoting energy efficiency.

The objective of these Directives is to promote the improvement of the energy performance of buildings within the Community, taking into account outdoor climatic and local conditions, as well as indoor climate requirements and costeffectiveness.

These Directives lay down requirements as regards: (a) general framework for a methodology of calculation of the integrated energy performance of buildings and building units; (b) application of minimum requirements on the energy performance of new buildings and new building units; (c) application of minimum requirements on the energy performance of: (i) existing buildings, building units and building elements that are subject to major renovation; (ii) building elements that form part of the building envelope and that have a significant impact on the energy performance of the building envelope when they are retrofitted or replaced; and (iii) technical building systems whenever they are installed, replaced or upgraded; (d) national plans for increasing the number of nearly zero- energy buildings; (e) energy certification of buildings or building units; (f) regular inspection of heating and air-conditioning systems in buildings; (g) independent control systems for energy performance certificates and inspection reports.

Together with an increased use of energy from renewable sources, measures taken to reduce energy consumption in the Union would allow the European Union to comply with the Kyoto Protocol to the United Nations Framework Convention on Climate Change (UNFCCC), and to honour both its long term commitment to maintain the global temperature rise below $2^{\circ} \mathrm{C}$, and its 
commitment to reduce, by 2020 , overall greenhouse gas emissions by at least $20 \%$ below 1990 levels, and by $30 \%$ in the event of an international agreement being reached.

With these purposes, the Directives require Member States to set minimum requirements on energy performance and introduce a system of energy performance certification for buildings. It also requires Member States to develop plans for low or zero carbon buildings, with the public sector leading the way.

\section{EPBD transpositions}

Table 1 shows the transposition of the EPBD to the different EU countries and Norway, as well as the Accountable Public Administrations (APAs).

Table 1: EPBD transpositions and APAs.

\begin{tabular}{|c|c|c|}
\hline COUNTRY & EPBD TRANSPOSITION & APAs \\
\hline Austria (AT) & $\begin{array}{l}\text { Energy Performance Certificate } \\
\text { Law (EAVG) [13] }\end{array}$ & $\begin{array}{l}\text { Austrian Institute of Construction } \\
\text { Engineering (OIB) }\end{array}$ \\
\hline $\begin{array}{l}\text { Belgium - Brussels } \\
\text { Capital Region (BE } \\
\text { BR) }\end{array}$ & $\begin{array}{l}\text { Brussels Air, Climate and } \\
\text { Energy Code (BE) [14] }\end{array}$ & $\begin{array}{l}\text { Regional Ministry of Energy of } \\
\text { the Government of the Brussels } \\
\text { Capital Region }\end{array}$ \\
\hline $\begin{array}{l}\text { Belgium - Flemish } \\
\text { Region (BE FR) }\end{array}$ & $\begin{array}{l}\text { Execution Order of May 11, } \\
2005, \text { adopted in } 2009 \text { [15] }\end{array}$ & Flemish Energy Agency (VEA) \\
\hline $\begin{array}{l}\text { Belgium - Walloon } \\
\text { Region (BE WR) }\end{array}$ & $\begin{array}{l}\text { Calculation Procedures and } \\
\text { Minimum Requirements for New } \\
\text { and Existing Buildings [16], } \\
\text { Certification of New Buildings } \\
\text { [17], Certification of Existing } \\
\text { Residential Buildings [18] and } \\
\text { Certification of Existing Non- } \\
\text { Residential Buildings [19] }\end{array}$ & $\begin{array}{l}\text { Department of Energy and } \\
\text { Sustainable Buildings }\end{array}$ \\
\hline Bulgaria (BG) & Energy Efficiency Act 2013 [20] & $\begin{array}{l}\text { Sustainable Energy Development } \\
\text { Agency (SEDA), supported by } \\
\text { the Ministry of Economy and } \\
\text { Energy and the Ministry of } \\
\text { Regional Development }\end{array}$ \\
\hline Croatia (HR) & $\begin{array}{l}\text { Physical Planning and Building } \\
\text { Act [21] and Energy Efficiency } \\
\text { Act [22] }\end{array}$ & $\begin{array}{l}\text { Ministry of Construction and } \\
\text { Physical Planning }\end{array}$ \\
\hline Cyprus (CY) & $\begin{array}{l}\text { Law for the Regulation of the } \\
\text { Energy Performance of } \\
\text { Buildings [23] }\end{array}$ & $\begin{array}{l}\text { Ministry of Energy, Commerce, } \\
\text { Industry and Tourism }\end{array}$ \\
\hline Czech Republic (CZ) & $\begin{array}{l}\text { Regulation on Energy } \\
\text { Performance of Buildings [24] }\end{array}$ & Ministry of Industry and Trade \\
\hline Denmark (DK) & $\begin{array}{l}\text { Danish Building Regulations } \\
\text { (BR10) [25] }\end{array}$ & Ministry of Business and Growth \\
\hline Estonia (EE) & $\begin{array}{l}\text { Minimum Energy Performance } \\
\text { Requirements [26] }\end{array}$ & $\begin{array}{l}\text { Ministry of Economic Affairs } \\
\text { and Communications }\end{array}$ \\
\hline Finland (FI) & National Building Code [27] & $\begin{array}{l}\text { Ministry of Environment and } \\
\text { Ministry of Employment and the } \\
\text { Economy }\end{array}$ \\
\hline
\end{tabular}


Table 1: Continued.

\begin{tabular}{|c|c|c|}
\hline COUNTRY & EPBD TRANSPOSITION & APAs \\
\hline France (FR) & $\begin{array}{l}\text { Energy Performance Diagnosis } \\
\text { (DPE) [28] }\end{array}$ & $\begin{array}{l}\text { Ministry of Ecology and } \\
\text { Sustainable Development Energy } \\
\text { and Ministry of Territories and } \\
\text { Housing }\end{array}$ \\
\hline Germany (DE) & $\begin{array}{l}\text { Energy Saving Ordinance } \\
\text { (EnEV) [29] and Renewable } \\
\text { Heating Law (EEWärmeG) [30] }\end{array}$ & $\begin{array}{l}\text { Federal Ministry of Transport, } \\
\text { Building and Urban } \\
\text { Development and Federal } \\
\text { Ministry of Economics and } \\
\text { Technology, under the } \\
\text { supervision of the Federal } \\
\text { Ministry for Environment, Nature } \\
\text { Conservation and Nuclear Safety }\end{array}$ \\
\hline Greece (EL) & $\begin{array}{l}\text { Law } 3361[31] \text {, KENAK } \\
\text { (Regulation for Energy } \\
\text { Performance of Buildings) [32], } \\
\text { Presidential Decree 100/NG177 } \\
\text { [33] }\end{array}$ & $\begin{array}{l}\text { Ministry of Environment, Energy } \\
\text { and Climate Change }\end{array}$ \\
\hline Hungary (HU) & $\begin{array}{l}\text { Ministerial Decree on the } \\
\text { Establishment of Energy } \\
\text { Characteristics of Buildings [34] } \\
\text { and Decree of Minister about } \\
\text { Determination of Energy } \\
\text { Efficiency of Buildings [35] }\end{array}$ & Ministry of Interior \\
\hline Ireland (IE) & $\begin{array}{l}\text { Dwelling Energy Assessment } \\
\text { Procedure (DEAP) and Non- } \\
\text { Dwelling Energy Assessment } \\
\text { Procedure (NEAP) [36] }\end{array}$ & $\begin{array}{l}\text { Department of the Environment, } \\
\text { Community and Local } \\
\text { Government (DECLG) }\end{array}$ \\
\hline Italy (IT) & $\begin{array}{l}\text { Decree on the Promotion of the } \\
\text { Use of Energy from Renewable } \\
\text { Sources [37] }\end{array}$ & $\begin{array}{l}\text { Ministry for Economic } \\
\text { Development }\end{array}$ \\
\hline Latvia (LV) & $\begin{array}{l}\text { Law on the Energy Performance } \\
\text { of Buildings (LEPB) [38] }\end{array}$ & Ministry of Economy \\
\hline Lithuania (LT) & $\begin{array}{l}\text { Law Energy Performance of } \\
\text { Buildings [39] }\end{array}$ & $\begin{array}{l}\text { Ministry of Environment and } \\
\text { Ministry of Energy }\end{array}$ \\
\hline Luxembourg (LU) & $\begin{array}{l}\text { Grand-Ducal Regulation on the } \\
\text { energy performance of buildings. } \\
\text { Memorial and Functional [40] }\end{array}$ & $\begin{array}{l}\text { Ministry of Economy and } \\
\text { Foreign Trade and Ministry of } \\
\text { Sustainable Development and } \\
\text { Infrastructure }\end{array}$ \\
\hline Malta (MT) & $\begin{array}{l}\text { Legal Notice of Minimum } \\
\text { Requirements on the Energy } \\
\text { Performance of Buildings [41], } \\
\text { Legal Notice of Energy } \\
\text { Performance of Buildings } \\
\text { Regulations [42] and Legal of } \\
\text { Energy Performance of } \\
\text { Buildings Regulations [43] }\end{array}$ & $\begin{array}{l}\text { The Building Regulation Office } \\
\text { (BRO) }\end{array}$ \\
\hline Netherlands (NL) & $\begin{array}{l}\text { Decree on Energy Performance } \\
\text { of Buildings (BEG) [44] and } \\
\text { Regulation on Energy } \\
\text { Performance of Buildings (REG) } \\
\text { [45] }\end{array}$ & $\begin{array}{l}\text { Ministry of the Interior and } \\
\text { Kingdom Relations }\end{array}$ \\
\hline Poland (PL) & Construction Act Journal [46] & $\begin{array}{l}\text { Ministry of Infrastructure and } \\
\text { Ministry of Economy }\end{array}$ \\
\hline
\end{tabular}


Table 1: Continued.

\begin{tabular}{|c|c|c|}
\hline COUNTRY & EPBD TRANSPOSITION & APAs \\
\hline Portugal (PT) & $\begin{array}{l}\text { System of Energy Certification } \\
\text { (SCE) [47], Regulation of } \\
\text { Energy Systems and } \\
\text { Climatization of Buildings } \\
\text { (RSECE) [48] and Regulation of } \\
\text { the Characteristics of Thermal } \\
\text { Conduct of Buildings (RCCTE) } \\
\text { [49] }\end{array}$ & $\begin{array}{l}\text { Ministry of Public Works, } \\
\text { Transport and Communications } \\
\text { Works }\end{array}$ \\
\hline Romania (RO) & $\begin{array}{l}\text { Law of Energy Performance of } \\
\text { Buildings [50]. }\end{array}$ & $\begin{array}{l}\text { Ministry of Regional } \\
\text { Development and Public } \\
\text { Administration }\end{array}$ \\
\hline Slovak Republic (SK) & $\begin{array}{l}\text { Act on the Energy Performance } \\
\text { of Buildings and on Amendment } \\
\text { and Supplements to Certain Acts } \\
\text { [51] }\end{array}$ & $\begin{array}{l}\text { Ministry of Construction and } \\
\text { Regional Development and } \\
\text { Ministry of Economy }\end{array}$ \\
\hline Slovenia (SI) & $\begin{array}{l}\text { Regulation on Energy } \\
\text { Performance [52] }\end{array}$ & $\begin{array}{l}\text { Ministry of the Economy, Energy } \\
\text { and Mining Inspectorate and } \\
\text { Ministry of Environment and } \\
\text { Spatial Planning }\end{array}$ \\
\hline Spain (ES) & $\begin{array}{l}\text { Basic Procedure for Certification } \\
\text { of Energy Efficiency of } \\
\text { Buildings [53], Regulation of } \\
\text { Thermal Installations in } \\
\text { Buildings (RITE) [54] and } \\
\text { Technical Code of Edification } \\
\text { (CTE) [55] }\end{array}$ & $\begin{array}{l}\text { Ministry of Industry, Energy and } \\
\text { Tourism and the Ministry of } \\
\text { Development }\end{array}$ \\
\hline Sweden (SE) & $\begin{array}{l}\text { Law on Energy Declaration of } \\
\text { Buildings [56], Performance } \\
\text { Certificates for Buildings } \\
\text { Ordinance [57] and Regulations } \\
\text { by the National Board of } \\
\text { Housing, Building and Planning } \\
\text { [58] }\end{array}$ & $\begin{array}{l}\text { Ministry of Enterprise, Energy } \\
\text { and Communications and } \\
\text { Ministry of the Environment }\end{array}$ \\
\hline $\begin{array}{l}\text { United Kingdom-- } \\
\text { England and Wales } \\
(\mathrm{UK}-\mathrm{EW})\end{array}$ & $\begin{array}{l}\text { Building Regulations } \\
\text { (amendments) Regulations [59] } \\
\text { Energy Performance of } \\
\text { Buildings [60] }\end{array}$ & Welsh Government \\
\hline $\begin{array}{l}\text { United Kingdom - } \\
\text { Northern Ireland (UK - } \\
\text { NI) }\end{array}$ & $\begin{array}{l}\text { Building Regulations [61] and } \\
\text { Energy Performance of } \\
\text { Buildings (Certificates and } \\
\text { Inspections) [62] }\end{array}$ & $\begin{array}{l}\text { Department of Finance and } \\
\text { Personnel Northern Ireland } \\
\text { (DFPNI) }\end{array}$ \\
\hline $\begin{array}{l}\text { United Kingdom - } \\
\text { Scotland }(\mathrm{UK}-\mathrm{S})\end{array}$ & $\begin{array}{l}\text { Building Act 2003, Building } \\
\text { Regulations 2004, Building } \\
\text { Procedure and Forms 2007, } \\
\text { Energy Performance of } \\
\text { Buildings Regulations } 2008 \text { [63] }\end{array}$ & $\begin{array}{l}\text { Directorate for the Built } \\
\text { Environment }\end{array}$ \\
\hline Norway (NO) & $\begin{array}{l}\text { Criteria for Passive Houses and } \\
\text { Low Energy Buildings [64] }\end{array}$ & $\begin{array}{l}\text { Water Resources and Energy } \\
\text { Directorate (NVE) }\end{array}$ \\
\hline
\end{tabular}




\section{Comparative analysis of the European energy rating systems}

Due to the large volume of information that can be deduced from the different transpositions indicated in Table 1, the most important aspects have been summarized in Table 2. The information from each country has been structured according to: (i) characteristics of the EPC (calculation methodology, types of dwellings, energy rating scale, registration, improvements and validity) and (ii) requirements of the QEs.

Table 2: Characteristics of EPCs and QEs.

\begin{tabular}{|c|c|c|c|c|c|c|c|c|c|c|c|c|}
\hline \multirow{3}{*}{\multicolumn{2}{|c|}{ Country }} & \multicolumn{9}{|c|}{ EPCs } & \multirow{2}{*}{\multicolumn{2}{|c|}{$\begin{array}{c}\text { QEs } \\
\text { Quality }\end{array}$}} \\
\hline & & \multicolumn{2}{|c|}{ Method } & \multicolumn{2}{|c|}{ Typology } & \multicolumn{2}{|c|}{ Scale } & \multicolumn{3}{|c|}{ Others } & & \\
\hline & & Demd & $\mathrm{AEC}$ & New & Exist & Levels & Cont & Reg & Imp & Valid & Cou & Ex \\
\hline \multicolumn{2}{|c|}{ AT } & $\mathrm{X}$ & - & $\mathrm{X}$ & $\mathrm{X}$ & 9 & - & - & - & 10 & - & - \\
\hline \multirow{3}{*}{$\mathrm{BE}$} & $\mathrm{BR}$ & $\bar{X}$ & - & $\mathrm{X}$ & $\bar{X}$ & 17 & - & $\mathrm{X}$ & $\mathrm{X}$ & 5 to 15 & $\mathrm{X}$ & - \\
\hline & FR & $\mathrm{X}$ & - & $\mathrm{X}$ & $\mathrm{X}$ & - & $\mathrm{X}$ & & $\mathrm{X}$ & 10 & $\mathrm{X}$ & $\mathrm{X}$ \\
\hline & WR & $\mathrm{X}$ & - & $\mathrm{X}$ & $\mathrm{X}$ & 8 & - & $\mathrm{X}$ & - & 10 & - & - \\
\hline \multicolumn{2}{|c|}{$\overline{\mathrm{BG}}$} & $\mathrm{X}$ & $\mathrm{X}$ & $\mathrm{X}$ & $\mathrm{X}$ & 7 & - & - & - & 3 to 10 & - & $\mathrm{X}$ \\
\hline \multicolumn{2}{|c|}{ HR } & $\mathrm{X}$ & - & $\mathrm{X}$ & $\mathrm{X}$ & 8 & - & $\mathrm{X}$ & $\mathrm{X}$ & 10 & $\mathrm{X}$ & $\mathrm{X}$ \\
\hline \multicolumn{2}{|c|}{$\mathrm{CY}$} & $\mathrm{X}$ & - & $\mathrm{X}$ & $\mathrm{X}$ & 7 & - & $\mathrm{X}$ & $\mathrm{X}$ & 10 & - & $\mathrm{X}$ \\
\hline \multicolumn{2}{|c|}{$\mathrm{CZ}$} & $\bar{X}$ & - & $\mathrm{X}$ & $\bar{X}$ & 7 & - & $\mathrm{X}$ & - & 10 & $\mathrm{X}$ & $\mathrm{X}$ \\
\hline \multicolumn{2}{|c|}{ DK } & $\mathrm{X}$ & - & $\mathrm{X}$ & $\mathrm{X}$ & 8 & - & - & - & 7 to 10 & - & - \\
\hline \multicolumn{2}{|c|}{ FI } & $\mathrm{X}$ & - & $\mathrm{X}$ & $\mathrm{X}$ & 8 & - & $\mathrm{X}$ & $\mathrm{X}$ & 10 & - & - \\
\hline \multicolumn{2}{|c|}{ FR } & $\mathrm{X}$ & $\mathrm{X}$ & $\mathrm{X}$ & $\mathrm{X}$ & 7 & - & $\mathrm{X}$ & $\mathrm{X}$ & 10 & - & $\mathrm{X}$ \\
\hline \multicolumn{2}{|c|}{$\mathrm{DE}$} & $\mathrm{X}$ & - & $\mathrm{X}$ & $\mathrm{X}$ & - & $X$ & $\mathrm{X}$ & $\mathrm{X}$ & 10 & - & - \\
\hline \multicolumn{2}{|c|}{ EE } & $\mathrm{X}$ & - & $\mathrm{X}$ & $\bar{X}$ & 8 & - & $\mathrm{X}$ & - & 10 & $\mathrm{X}$ & $\mathrm{X}$ \\
\hline \multirow{2}{*}{\multicolumn{2}{|c|}{$\begin{array}{l}\text { EL } \\
\text { HU }\end{array}$}} & $\mathrm{X}$ & - & $\mathrm{X}$ & $\mathrm{X}$ & 9 & - & $\mathrm{X}$ & $\mathrm{X}$ & 10 & $\mathrm{X}$ & $\mathrm{X}$ \\
\hline & & $\mathrm{X}$ & - & $\mathrm{X}$ & $\mathrm{X}$ & 9 & - & $\mathrm{X}$ & & 10 & $\mathrm{X}$ & - \\
\hline \multicolumn{2}{|c|}{$\mathrm{IE}$} & $\mathrm{X}$ & $\mathrm{X}$ & $\mathrm{X}$ & $\mathrm{X}$ & 15 & - & $\mathrm{X}$ & $\mathrm{X}$ & 10 & - & $\mathrm{X}$ \\
\hline \multicolumn{2}{|c|}{ IT } & $\mathrm{X}$ & - & $\mathrm{X}$ & $\bar{X}$ & 8 & - & $\mathrm{X}$ & - & 10 & $\mathrm{X}$ & $\mathrm{X}$ \\
\hline \multicolumn{2}{|c|}{ LV } & $\mathrm{X}$ & $\mathrm{X}$ & $\mathrm{X}$ & - & - & $\mathrm{X}$ & $\mathrm{X}$ & - & 10 & - & $X$ \\
\hline \multicolumn{2}{|c|}{ LT } & $\mathrm{X}$ & - & $\mathrm{X}$ & $\mathrm{X}$ & 9 & - & $\mathrm{X}$ & - & 10 & $\mathrm{X}$ & $\mathrm{X}$ \\
\hline \multicolumn{2}{|c|}{$\mathrm{LU}$} & $\mathrm{X}$ & $\mathrm{X}$ & $\mathrm{X}$ & $\mathrm{X}$ & 9 & - & $\mathrm{X}$ & $\mathrm{X}$ & 10 & - & - \\
\hline \multicolumn{2}{|c|}{ MT } & $X$ & $X$ & $X$ & $X$ & 7 & - & $X$ & - & 10 & $X$ & - \\
\hline & & $\mathrm{X}$ & - & $\mathrm{X}$ & $\mathrm{X}$ & 9 & - & $\mathrm{X}$ & $\mathrm{X}$ & 10 & - & $\mathrm{X}$ \\
\hline & & $\mathrm{X}$ & - & $\mathrm{X}$ & $\mathrm{X}$ & - & $\mathrm{X}$ & $\mathrm{X}$ & - & 10 & $\mathrm{X}$ & $\mathrm{X}$ \\
\hline & & $X$ & $X$ & $\mathrm{X}$ & $\mathrm{X}$ & 9 & - & $\mathrm{X}$ & $X$ & 2 to 6 & $X$ & $\mathrm{X}$ \\
\hline & & $\mathrm{X}$ & $\mathrm{X}$ & $\mathrm{X}$ & $\mathrm{X}$ & 7 & - & $\mathrm{X}$ & $\mathrm{X}$ & 5 & $\mathrm{X}$ & $X$ \\
\hline & & $\mathrm{X}$ & - & $\mathrm{X}$ & $\mathrm{X}$ & 8 & - & & $\mathrm{X}$ & 10 & $\mathrm{X}$ & $\mathrm{X}$ \\
\hline & & $\mathrm{X}$ & $X$ & $\mathrm{X}$ & $X$ & 7 & - & $\mathrm{X}$ & - & 10 & $\mathrm{X}$ & - \\
\hline & & $\mathrm{X}$ & $\mathrm{X}$ & $\mathrm{X}$ & $\mathrm{X}$ & 9 & - & $\mathrm{X}$ & $\mathrm{X}$ & 10 & - & - \\
\hline & & - & $\mathrm{X}$ & $\mathrm{X}$ & $\mathrm{X}$ & 7 & - & $\mathrm{X}$ & $\mathrm{X}$ & 10 & - & $\mathrm{X}$ \\
\hline & EW & $\mathrm{X}$ & - & $\mathrm{X}$ & $\mathrm{X}$ & 7 & - & $\mathrm{X}$ & $\mathrm{X}$ & 10 & - & - \\
\hline UK & NI & $\mathrm{X}$ & - & $\mathrm{X}$ & $\mathrm{X}$ & 7 & - & $\mathrm{X}$ & $\mathrm{X}$ & 10 & - & - \\
\hline & $\mathrm{S}$ & $\mathrm{X}$ & $\mathrm{X}$ & $\mathrm{X}$ & $\mathrm{X}$ & 7 & - & $\mathrm{X}$ & $\mathrm{X}$ & 10 & - & - \\
\hline & & $\mathrm{X}$ & - & $\mathrm{X}$ & $\mathrm{X}$ & 7 & - & $\mathrm{X}$ & $\mathrm{X}$ & 10 & - & - \\
\hline
\end{tabular}

Demd: Demand; AEC: Actual energy consumption; Exist: Existing; L: Levels; Cont: Continuous; Reg: Registry; Imp: Improvements; Valid: Validity (years); Cou: Course; Ex: Exam 


\subsection{Energy Performance Certificates (EPCs)}

The EPCs calculation method is very similar in all countries, using the annual energy demand of the building to calculate the energy rating. However, the calculation method in Sweden is based on the real quantity of energy used, and other countries use a combination of both methods for the energy rating of the building (Table 2).

In the case of calculating the EPC by using the annual energy demand of the building, it is necessary to be very precise in defining the building envelope, materials, thermal bridges, heating and cooling, DHW, etc. This is due to the fact that this method is based on a prediction. This method has the advantage of knowing how the building is going to work before use in normal conditions. However, calculating the real amount of energy used, the measurement may vary between identical buildings in the same climate zone because of the human factor involved in the calculation method [65], although a more individualized result to each dwelling is obtained.

From the transposition of the EPBD, the EPC is carried out in the project phase in all countries except in Latvia, where the EPC is also performed in the existing buildings that are going to be sold or rent. As an exception, the EPC is not required in Sweden when the dwelling is going to be sold or rent to a member of the owner's family.

Table 2 shows the scale to carry out the energy rating. As it can be observed, not all EU countries have adopted the same scale, ranging from scales with 7 levels (BG, CY, CZ, FR, MT, RO, SE, UK and NO) to scales of 17 levels (BE$\mathrm{BR})$. On the other hand, some of the countries have adopted a continuous scale (BE-FR, DE, LV and PL).

The registry of the EPC is mandatory in the majority of States. Moreover, it is compulsory to include proposals for energy improvement in the EPC. The validity of the EPC is 10 years generally, varying in some States due to variations such as the power of the heating and cooling facilities.

Regarding the price of the EPC, in the majority of the countries the price corresponds to the market price. Only Hungary has a fixed price that is established by the government.

\subsection{Qualified Experts (QEs)}

As is shown in Table 2, not all the countries have the same requirements for QEs. In some countries, a degree in architecture or engineering is required, whereas in other countries it is necessary to pass a course and/or an exam in addition to a university degree. The accreditation to QE may be given by the State, but the State can delegate this function to other bodies such as professional associations that would perform the courses and exams needed.

To know the available QEs, some States have online registers that can be consulted by the public. In other States it is necessary to go to professional associations where there are lists of the QEs. On the other hand, there are some States where this information is not public. 
Another feature is that QEs can be divided into different categories. In countries with only one category of QEs, the inspection of buildings and facilities can be performed by the same expert, whereas there are countries with different categories of QE depending on building typologies and/or power of the facilities.

\section{Conclusions}

The transposition of the European framework to each country has created a series of regulations with the same origin but not homogeneous among themselves.

With the current transpositions it is impossible to compare the energy efficiency of two identical buildings in different States, even having the same climatic conditions, because the energy scales are different, as well as the calculation methods (energy demand, real consumption or both).

A QE in a State could not work in another State of the European Union as a $\mathrm{QE}$ because of the different requirements of each one. This fact impedes the free circulation of professionals.

Therefore, this study states the importance of a more homogeneous transposition of the EPBD in the different countries of the European Union, showing substantial differences between them in spite of being developed to achieve the same objective, which is the reduction of the energy consumption in dwellings by a proper building design.

\section{Acknowledgement}

This research is funded by the Spanish Ministry of Economy and Competitiveness (Research Project TEC2012-38883-C02-02)

\section{References}

[1] Florides GA, Christodoulides P, Messaritis V, Reviewing the effect of $\mathrm{CO} 2$ and the sun on global climate. Renewable and Sustainable Energy Reviews, 26, pp. 639-51, 2013.

[2] United Nations, Kyoto protocol to the United Nations framework convention on climate change. 1997.

[3] European Parliament and of the Council, Directive 2002/91/EC of the European Parliament and of the Council of 16 December on the energy performance of buildings. DOUE 1, pp. 65-71, 2003.

[4] European Parliament and of the Council, Directive 2010/31/EU of the European Parliament and of the Council of 19 May on the energy performance of buildings. DOUE 153, pp. 13-35, 2010.

[5] Newton D, James R, Bartholomew D, Building energy simulation - A user's perspective. Energy Build, 10, pp. 241-7, 1988.

[6] Rey FJ, Velasco E, Varela F, Building Energy Analysis: A methodology to assess building energy labelling. Energy Build, 39, pp. 709-16, 2007. 
[7] Pisello AL, Goretti M, Cotana F, A method for assessing buildings' energy efficiency by dynamic simulation and experimental activity. Appl Energy, 97, pp. 419-29, 2012.

[8] Spalding-Fecher R, Winkler H, Mwakasonda S, Energy and the World Summit on Sustainable Development: what next? Energy Policy, 33, pp. 99-112, 2005.

[9] Pouffary S, Cheng C, Svenningsen N, Reducing greenhouse gas emissions from the building sector under the Kyoto Protocol. Challenges and opportunities. Climate Change: Global Riks, Challenges and Decisions, 6, pp. 202005, 2009.

[10] Cheng C, Pouffary S, Svenningsen N, Callaway M. The Kyoto Protocol, The Clean Development Mechanism and the Building and Construction Sector - A Report for the UNEP Sustainable Buildings and Construction Initiative. Paris, France: United Nations Environment Programme, 2008.

[11] Tronchin L, Fabbri K, Energy performance building evaluation in Mediterranean countries: Comparison between software simulations and operating rating simulation. Energy Build, 40, pp. 1176-87, 2008.

[12] Andaloro APF, Salomone R, Ioppolo G, Andaloro L, Energy certification of buildings: A comparative analysis of progress towards implementation in European countries. Energy Policy, 38, pp. 5840-66, 2010.

[13] Austrian Institute of Construction Engineering (OIB), EnergieausweisVorlage-Gesetz (Energy Performance Certificate Law). EAVG, 2012.

[14] Regional Ministry of Energy, Government of the Brussels Capital Region, Brussels Air, Climate and Energy Code. BE on 19 April, 2013.

[15] Flemish Energy Agency (VEA), Government of Belgium, Execution Order of May 11, 2005, adopted in 2009. 2009.

[16] Department of Energy and Sustainable Buildings, Government of Belgium, Calculation procedures and minimum requirements for new and existing buildings. $M B d u$ 22/06/2012, pp. 34014, 2012.

[17] Department of Energy and Sustainable Buildings, Government of Belgium, Certification of new buildings. $M B d u$ 05/09/2011, pp. 56370, 2011.

[18] Department of Energy and Sustainable Buildings, Government of Belgium, Certification of existing residential buildings. $M B d u$ 07/06/2010, pp. 35958, 2010.

[19] Department of Energy and Sustainable Buildings, Government of Belgium, Certification of existing non-residential buildings. $M B d u$ 03/11/2011, pp. 65830, 2011.

[20] Ministry of Economy and Energy, Government of Bulgaria, Energy Efficiency Act. SG 24/12 032013.

[21] Ministry of Construction and Physical Planning, Government of Croatia, Physical Planning and Building Act. Official Gazete No. 76, 2007.

[22] Ministry of Construction and Physical Planning, Government of Croatia, Energy Efficiency Act. Official Gazete No. 152, 2008. 
[23] Ministry of Energy, Commerce, Industry and Tourism, Government of Cyprus, Law for the Regulation of the Energy Performance of Buildings. L 142(I)/2006, 2006.

[24] Ministry of Industry and Trade, Government of Czech Republic, Regulation on Energy Performance of Buildings. Regulation 148/2007, 2007.

[25] Ministry of Business and Growth, Government of Denmark, Danish Building Regulations. BR10, 2010.

[26] Ministry of Economic Affairs and Communications, Government of Estonia, Minimum Requirements for Energy Efficiency. Decree $n r$ 258, 2009.

[27] Ministry of Environment, Government of Finland, National Building Code. NBD 2013, 2013.

[28] Ministry of Ecology and Sustainable Development Energy, Government of France, Diagnostic de Performance Énergétique (DPE). décret no 2011413 du 13 avril, JORF 0092, pp. 6840, 2011.

[29] Federal Ministry of Transport, Building and Urban Development, Government of Germany, Energieeinsparverordnung für Gebäude (EnEV). 2009.

[30] Federal Ministry for Environment, Nature Conservation and Nuclear Safety, Government of Germany, Erneuerbaren-Energien-Wärmegesetz (EEWärmeG). 2009.

[31] Ministry of Environment, Energy and Climate Change, Government of Greece, Transposition of the EPBD. Law 3661 (18 may 2008), 2008.

[32] Ministry of Environment, Energy and Climate Change, Government of Greece, KENAK (Regulation for Energy Performance of Buildings). Ministerial decision D6/B/5825, National Gazette 407, 2010.

[33] Ministry of Environment, Energy and Climate Change, Government of Greece, Presidential Decree 100/NG177. National Gazette 6th of October, 2010.

[34] Ministry of Interior, Government of Hungary, Ministerial Decree on the establishment of energy characteristics of buildings . MD TNM 7/2006,24, 2006.

[35] Ministry of Interior, Government of Hungary, Decree of Minister without Portfolio About Determination of Energy Efficiency of Buildings. Hungarian Decree 40/2012,13, 2012.

[36] Department of the Environment, Community and Local Government (DECLG), Government of Ireland, Dwelling Energy Assessment Procedure (DEAP) and Non- Dwelling Energy Assessment Procedure (NEAP). SI 243 of 2012, 2012.

[37] Ministry for Economic Development, Government of Italy, Fourth Conto Energia. Decree 28/2011, 2011.

[38] Ministry of Economy, Government of Latvia, Ēku energoefektivitātes likums. Law on the Energy Performance of Buildings (LEPB). 2008.

[39] Ministry of Energy, Government of Lithuania, Law on Energy, Energy Performance of Buildings. STR 201 09, 2005. 
[40] Ministry of Economy and Foreign Trade, Government of Luxembourg, Règlement grand-ducal modifié du 31 août 2010 concernant la performance énergétique des bâtiments fonctionnels. $A N^{o} 173$ de 2010, 2010.

[41] Ministry for Resources and Rural Affairs, Government of Malta, Minimum Requirements on the Energy Performance of Buildings. Legal Notice 238 of 2006, 2006.

[42] Ministry for Resources and Rural Affairs, Government of Malta, Energy Performance of Buildings Regulations. Legal Notice 261 of 2008, 2008.

[43] Ministry for Resources and Rural Affairs, Government of Malta, Energy Performance of Buildings Regulations. Legal Notice 376 of 2012, 2012.

[44] Ministry of the Interior and Kingdom Relations, Government of the Netherlands, Decree on Energy Performance of Buildings (BEG). 2006.

[45] Ministry of the Interior and Kingdom Relations, Government of the Netherlands, Energy Performance of Buildings (REG). 2009.

[46] Ministry of Infrastructure, Government of Poland, Construction Act Journal. Laws No 191,1373, 2009.

[47] Ministério da Economia e da Inovação, Government of Portugal, Sistema de certificação energética (SCE). Decreto-Lei n o 78/2006 de 4 de abril, DR 67, pp. 2411-5, 2006.

[48] Ministério das Obras Públicas, Transportes e Comunicações, Government of Portugal, Regulamento dos Sistemas Energéticos e de Climatização nos Edifícios (RSECE). Decreto-Lei $n$ o 79/2006 de 4 de Abril, DR 67, pp. 2416-68, 2006.

[49] Ministério das Obras Públicas, Transportes e Comunicações, Government of Portugal, Regulamento das Características de Comportamento Térmico dos Edifícios (RCCTE). Decreto-Lei $n$ o 80/2006 de 4 de Abril, DR 67, pp. 2468-513, 2006.

[50] Ministry of Regional Development and Public Administration, Government of Romania, Law of energy performance of buildings. Law 372/2005, 2005.

[51] Ministry of Construction and Regional Development, Government of Slovakia, Energy Performance of Buildings and on Amendment and Supplements to Certain Acts. Act 555/2005, 2005.

[52] Ministry of the Economy, Energy and Mining Inspectorate, Government of Slovenia, Regulation on Energy Performance. 2010.

[53] Ministerio de la Presidencia, Government of Spain, Procedimiento básico para la certificación de la eficiencia energética de los edificios. Real Decreto 235/2013, de 5 de abril, BOE 89, pp. 27548-62, 2013.

[54] Ministerio de Industria, Turismo y Comercio, Government of Spain, Ministerio de la Vivienda, Government of Spain, Reglamento de Instalaciones Térmicas en los Edificios (RITE). Real Decreto 1027/2007 de 20 de julio, BOE 207, pp. 35931-84, 2007.

[55] Ministerio de la Vivienda, Government of Spain, Código Técnico de la Edificación (CTE). Real Decreto 314/2006 de 17 de marzo, BOE 74, pp. 11816-31, 2006. 
[56] Ministry of Enterprise, Energy and Communications, Government of Sweden, Law on Energy Declaration of Buildings. Law (2006:685), 2006.

[57] Ministry of Enterprise, Energy and Communications, Government of Sweden, Performance Certificates for Buildings Ordinance. Ordinance 2006:1592, 2006.

[58] Ministry of Enterprise, Energy and Communications, Government of Sweden, National Board of Housing, Building and Planning. 2012.

[59] Welsh Government, Building Regulations (amendments) Regulations. Statutory Instrument 2012/3119, 2012.

[60] Welsh Government, Energy Performance of Buildings. Statutory Instrument 2012/3118, 2012.

[61] Department of Finance and Personnel Northern Ireland (DFPNI), Building Regulations. Statutory Rule 2012 No 192, 2012.

[62] Department of Finance and Personnel Northern Ireland (DFPNI), Energy Performance of Buildings (Certificates and Inspections). Statutory Rule $2008 N^{\circ} 170,2008$.

[63] Directorate for the Built Environment, Government of Scotland, Energy Performance of Buildings Regulations. 2008.

[64] Water Resources and Energy Directorate (NVE), Government of Norway, Criteria for passive houses and low energy buildings. NS 3701, 2012.

[65] Zabalza I, Díaz S, Aranda A. Manual práctico de certificación energética de edificios. Zaragoza: Universidad de Zaragoza, 2009. 